\title{
UHLONOSNOST SVRCHNÍCH HRUŠOVSKÝCH VRSTEV (NAMUR) V ČESKÉ ČÁSTI HORNOSLEZSKÉ PÁNVE
}

\author{
Coal-bearing capacity of the Upper Hrušov Member (Namurian) in the Czech part \\ of the Upper Silesian Basin \\ Luboš Beneš1, Jakub Jirásek', Lada Hýlová2, Martin Sivek' \\ 'Institut geologického inženýrství, Hornicko-geologická fakulta, Vysoká škola báňská - Technická univerzita Ostrava, \\ 17. listopadu 15/2172, 70833 Ostrava-Poruba; e-mail:jakub.jirasek@vsb.cz \\ ${ }^{2}$ Katedra geologie PřF UP, 17. listopadu 1192/12, 77146 Olomouc
}

(15-41 Hlučín, 15-42 Bohumín, 15-43 Ostrava, 15-44 Karviná, 25-21 Nový Jičín, 25-22 Frýdek Místek)

Key words: Mississippian, Ostrava Formation, coal-bearing capacity, computer modelling

\begin{abstract}
Maps of the coal-bearing capacity, number and total thickness of coal seams of the Upper Hrušov Member (Namurian, Mississippian) were made. They are based on exploratory boreholes' information from the Czech part of the Upper Silesian Basin. Absolute coal-bearing capacity varies from $0.00 \%$ to $2.57 \%$, and their total thickness from $0.00 \mathrm{~m}$ to $9.43 \mathrm{~m}$. All mentioned parameters reach their maximum in NNE-SSW trending zone west of the Orlová Structure. This situation supports the hypothesis, that preserved part of the Upper Hrušov Member could form the subsidence axis of the basin and its eastern part whereas the western part is not preserved due to post-Carboniferous erosion, similar as in the case of Lower Hrušov Member.
\end{abstract}

\section{Úvod}

V analýzách vývoje uhelných pánví představuje uhlonosnost běžně používaný parametr. Jeho význam je dvojí. Jednak je to významný báňsko-technický parametr používaný v oblasti hodnocení uhelných ložisek, ve výpočtech uhelných zásob a klasifikacích báňských podmínek, jednak důležitý parametr pro zkoumání historie vývoje pánve a jejích paleogeografických pomèrů. Uhlonosnost je možno vyjádřit několika způsoby. Jako:

1. součet uhelných poloh $\mathrm{v}$ metrech ve sledované části vrstevního sledu,

2. počet uhelných poloh ve sledované části vrstevního sledu,

3. poměr celkové mocnosti uhelných poloh (slojí) k celkové mocnosti vrstevního sledu v procentech ve sledované části vrstevního sledu.

Termínem uhlonosnost je zpravidla označován poslední $z$ výše uvedených způsobů stanovení obsahu uhelné hmoty v sedimentech, který se rovněž použivá $\mathrm{k}$ odhadu množství zásob $\mathrm{v}$ uhelných ložiscích $\mathrm{s}$ nízkým stupněm prozkoumanosti. První dva způsoby stanovení obsahu uhelné hmoty v sedimentech se používají více v sedimentologických aplikacích.

Protože uhelné polohy mohou mít $\mathrm{v}$ sedimentech různou mocnost, od lamin mocných několik milimetrů až po polohy uhlí několik desítek metrů mocné, je třeba u každého výpočtu uhlonosnosti stanovit tzv. mezní mocnost, což je minimální mocnost uhelných poloh, které jsou do výpočtu uhlonosnosti zahrnuty. Bez stanovení mezní mocnosti nemá informace o uhlonosnosti žádnou výpovědní schopnost a pro interpretace ani další aplikace se v podstatě nedá použít. Podle mezní mocnosti se při sledování uhlonosnosti stanovuje zpravidla absolutní (celková) uhlonosnost $\left(\mathrm{U}_{\mathrm{A}}{ }^{10}\right)$, což je uhlonosnost s mezní mocností $0,10 \mathrm{~m}$ a dále různé tzv. ložiskové uhlonosnosti.
Nejčastěji se požívá ložisková uhlonosnost $\mathrm{s}$ mezní mocností $0,40 \mathrm{~m}\left(\mathrm{U}_{\mathrm{L}}^{40}\right)$, což byla po dlouhou dobu minimální mocnost evidovaných černouhelných slojí na území dnešní České republiky, př́ípadně ložisková uhlonosnost s mezní mocností $0,80 \mathrm{~m}\left(\mathrm{U}_{\mathrm{L}}{ }^{80}\right)$, což byla častá minimální mocnost bilančních zásob černého uhlí. $\mathrm{V}$ původní práci Beneše (2011) byly pro každou uvedenou mezní mocnost stanoveny následující varianty (typy) uhlonosnosti:

1. uhlonosnost vyjádřená součtem uhelných poloh v metrech ve sledované části vrstevního sledu,

2. uhlonosnost vyjádřená poměrem celkové mocnosti uhelných poloh (slojí) k celkové mocnosti vrstevního sledu v procentech ve sledované ćásti vrstevního sledu.

Bylo tedy sestaveno celkem šest modelů vývoje uhlonosnosti svrchních hrušovských vrstev $\mathrm{v}$ české ćásti hornoslezské pánve (dále jen ČHP), které byly použity k interpretaci a formulaci výsledků výzkumu. Tuto zprávu o výzkumu doplňujeme třemi modely, na nichž dokumentujeme vývoj uhlonosné sedimentace v období vzniku svrchních hrušovských vrstev (obr. 1, 2,3). Jde o modely uhlonosnosti a to pro mocnosti uhelných poloh větších než $0,10 \mathrm{~m}, 0,40 \mathrm{~m}$ a $0,80 \mathrm{~m}$. Na zbylé modely odkazujeme $\mathrm{v}$ textu nebo používáme číselné hodnoty jejich výsledkủ.

\section{Geologická charakteristika svrchních \\ hrušovských vrstev}

Geologická charakteristika české části hornoslezské pánve (dále jen ČHP), vývoje a stavby svrchních hrušovských vrstev, včetně jejich základní literatury jsou uvedeny v článku Beneše et al. (2013 - v tomto čísle).

\section{Metodika}

Základní metodika, datová základna a topografie pánve použité $\mathrm{v}$ této práci jsou podrobně popsány $\mathrm{v}$ článku Beneše et al. (2013 - v tomto č́sle). 


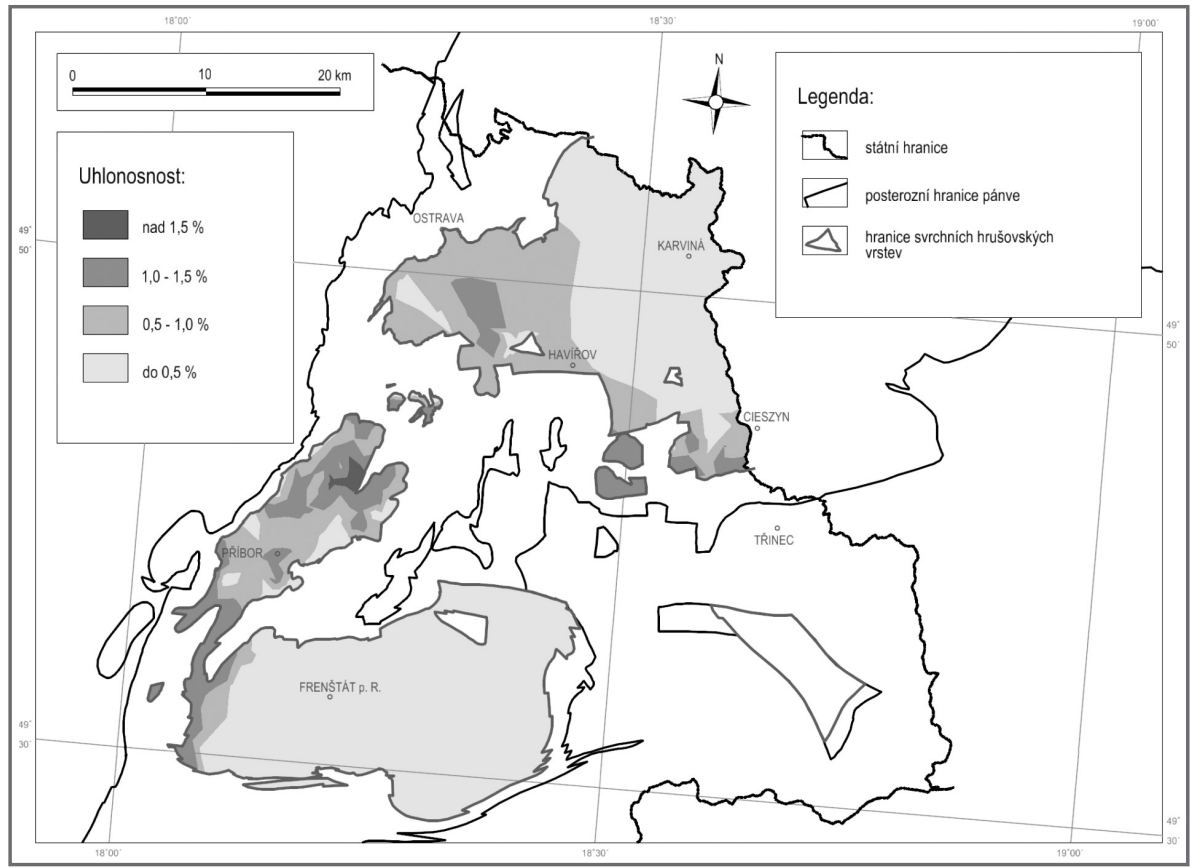

Obr. 1: Uhlonosnost $\mathrm{U}_{\mathrm{A}}{ }^{10}$ svrchních hrušovských vrstev v české části hornoslezské pánve.

Fig. 1: Coal-bearing capacity $\mathrm{U}_{\mathrm{A}}{ }^{10}$ of the Upper Hrušov Member in the Czech part of the Upper Silesian Basin.

Mapy různých typů uhlonosnosti vznikly na základě počítačových modelů, které byly vytvořeny vyhodnocením a zpracováním profilů povrchových průzkumných vrtů realizovaných převážně v období od roku 1946 do roku 2000. Seznam použitých vrtů uvádí Beneš (2011). V české části hornoslezské pánve ověřilo svrchní hrušovské vrstvy 160 vrtů $\mathrm{z}$ povrchu. Úplnou mocnost provrtalo 65 vrtů (40,6 \%), zbývajících 95 vrtů (59,4 \%) jsou vrty neúplné, které ověřily pouze část mocnosti této vrstevní jednotky. Hodnoty parametrů potřebné k vytvoření modelů vývoje uhlonosnosti byly získány z geologické dokumentace ložiskových průzkumných vrtů. Jednalo se o nepravé mocnosti uhelných poloh, které byly přepočteny na pravé mocnosti podle hodnot úklonů uvedených v geologické dokumentaci vrtu. Do stanovení hodnot byla zahrnuta uhlí všech technologických typů i popelnatostí s výjimkou uhelných jílovců. Tyto do výpočtů nebyly zahrnuty.

\section{Uhlonosnost svrchních hrušovských vrstev}

Vývoj uhlonosnosti svrchních hrušovských vrstev v ČHP vykazuje některé zákonitosti, které zapadají do sedimentologického vý- voje této vrstevní jednotky. Pro jednotlivé mezní mocnosti lze hlavní trendy vývoje uhlonosnosti definovat následujícím způsobem.

\section{Celková uhlonosnost $\mathrm{U}_{\mathrm{A}}{ }^{10}$ (obr. 1)}

Celková mocnost uhelných poloh o mocnosti vyšší než $0,10 \mathrm{~m}$ má obdobný vývoj jako celková mocnost uhelných poloh ve svrchních hrušovských vrstvách, která se pohybuje $\mathrm{v}$ rozmezí hodnot od 0,00 m do 9,43 m. Pro plošný vývoj uhlonosnosti je typické, že v ČHP leží oblasti vyšších hodnot v pásmu protaženém ve směru SV-JZ, západně od orlovské struktury, př́padně ji jen mírně přesahují východním směrem (obr. 1).

Východ české části hornoslezské pánve má z hlediska uhlonosnosti opačný vývoj, pro který jsou charakteristické nízké až nulové hodnoty uhlonosnosti. Ty nacházíme na SV Karvinska, zejména však na Frenštátsku, kde pokrývají jeho převážnou část (až 80 \%), s výjimkou dvou ostrůvků v jeho severní a severozápadní části. I v těch však celková mocnost uhelných poloh dosahuje velmi nízkých hodnot. Ve vývoji uhlonosnosti svrchních hrušovských vrstev se tak uplatňuje zřetelná východozápadní polarita. Vedle ní lze však rozlišit i polaritu

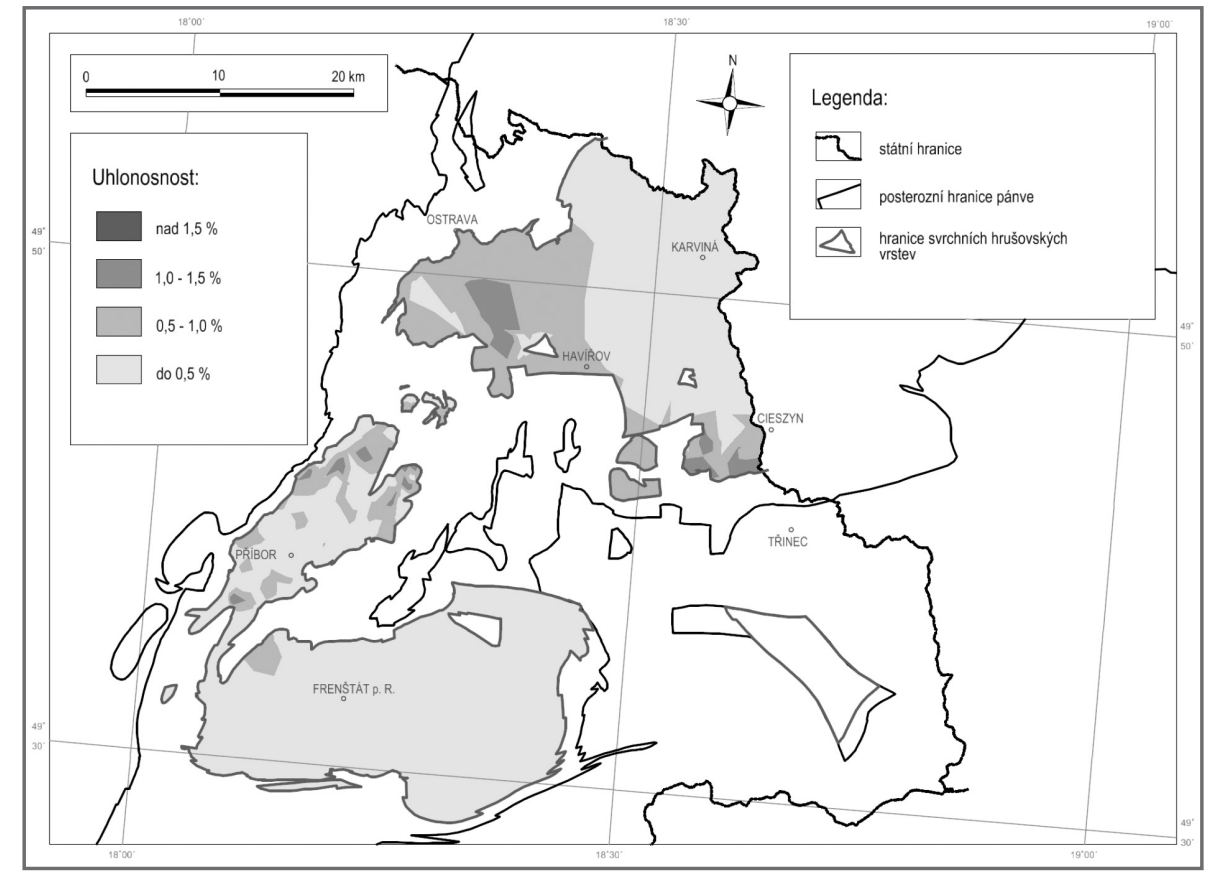

Obr. 2: Uhlonosnost $\mathrm{U}_{\mathrm{L}}{ }^{40}$ svrchních hrušovských vrstev $\mathrm{v}$ české části hornoslezské pánve. Fig. 2: Coal-bearing capacity $\mathrm{U}_{\mathrm{L}}{ }^{40}$ of the Upper Hrušov Member in the Czech part of the Upper Silesian Basin. 
sj., která se projevuje podstatně větším zastoupením ploch s nulovou uhlonosností na J české části hornoslezské pánve. Příčinu tohoto jevu lze nepochybně hledat $\mathrm{v}$ redukci svrchních hrušovských vrstev východním smèrem a částečně i směrem jižním, která je doprovázená nárůstem písčitosti a ústupem cyklické stavby uhlonosných sekvencí. Plochy vyšších hodnot uhlonosnosti mají zpravidla nepravidelný obrys. Lze to dobře pozorovat v mořkovské oblasti, kde prozkoumanost vrstevní jednotky vrty z povrchu je relativně vyšší, než je tomu v ostravsko-karvinské oblasti. Výsledky analýzy prostorového vývoje uhlonosnosti vyjádřené celkovou mocností

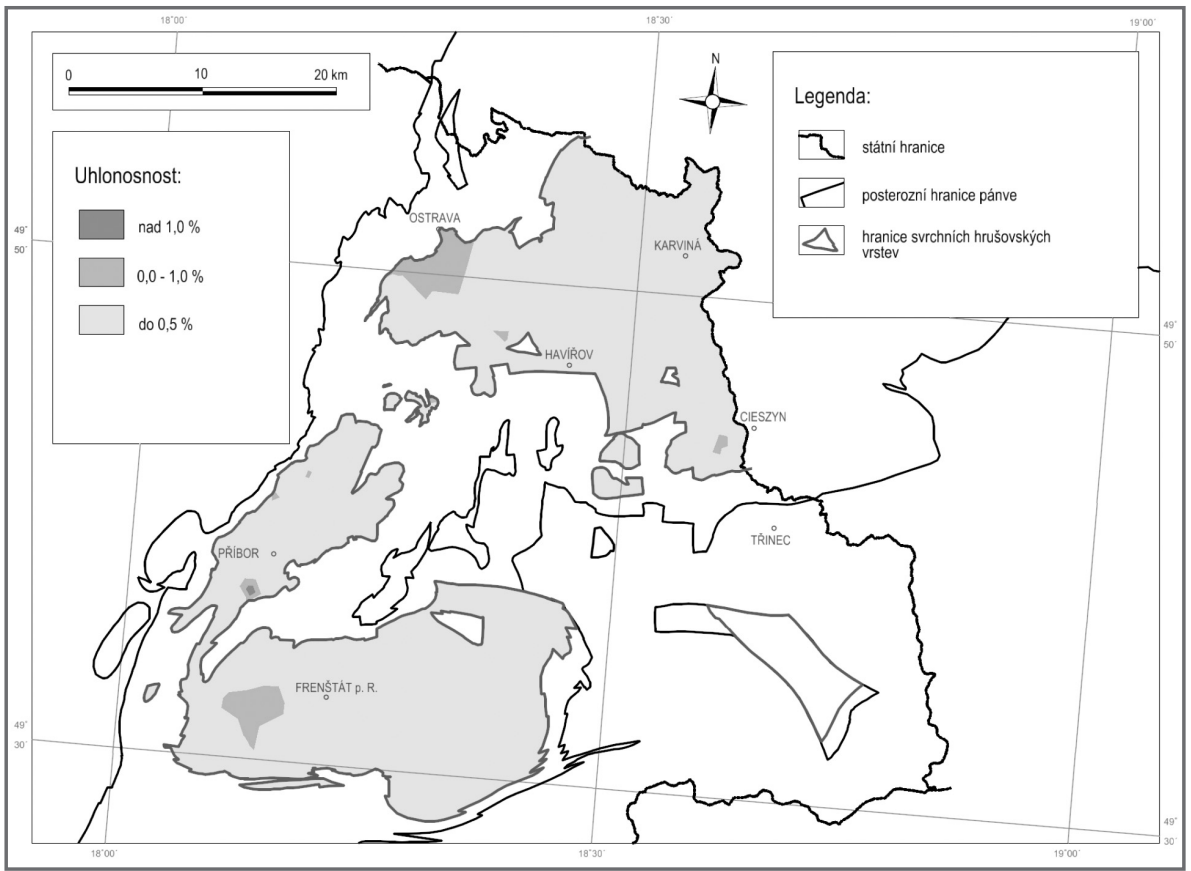

Obr. 3: Uhlonosnost $\mathrm{U}_{\mathrm{L}}{ }^{80}$ svrchních hrušovských vrstev v české části hornoslezské pánve.

Fig. 3: Coal-bearing capacity $\mathrm{U}_{\mathrm{L}}{ }^{80}$ of the Upper Hrušov Member in the Czech part of the Upper Silesian Basin. uhelných poloh o mocnosti vyšší než $0,10 \mathrm{~m}$ doplňujeme procentuálními hodnotami uhlonosnosti o stejné mezní mocnosti uhelných poloh. Hodnoty tohoto parametru se pohybují od nuly do 2,57\%. Jejich prostorová distribuce je obdobou analyzovaného vývoje uhlonosnosti vyjádřené celkovou mocností uhelných poloh.

\section{Ložisková uhlonosnost $\mathrm{U}_{\mathrm{L}}{ }^{40}$ (obr. 2)}

Celková mocnost uhelných poloh o mocnosti vyšší než $0,40 \mathrm{~m}$ se ve svrchních hrušovských vrstvách pohybuje $\mathrm{v}$ rozmezí hodnot od $0 \mathrm{~m}$ do $7,7 \mathrm{~m}$. Obraz vývoje uhlonosnosti tohoto typu je obdobou vývoje uhlonosnosti vyjádřené celkovou mocností uhelných poloh o mocnosti vyšší než 0,10 m. Plošné rozsahy vyšších hodnot jsou však menší, naproti tomu došlo ke zvětšení ploch s nulovými nebo nízkými hodnotami tohoto typu uhlonosnosti. Tato změna je dobře patrná ze srovnání procentuálních hodnot uhlonosnosti. To jen dokumentuje skutečnost, že na uhlonosnosti svrchních hrušovských vrstev se více podílí sloje nízkých mocností.

Ložisková uhlonosnost $U_{\mathrm{L}}{ }^{80}$ (obr. 3)

Celková mocnost uhelných poloh o mocnosti vyšší než $0,80 \mathrm{~m}$ se ve svrchních hrušovských vrstvách pohybuje v rozmezí hodnot od $0 \mathrm{~m}$ do 5,68 m. Obraz vývoje uhlonosnosti tohoto typu je obdobou vývoje uhlonosností vyjádřených celkovou mocností uhelných poloh o mocnosti vyšší než $0,10 \mathrm{~m}$ a $0,40 \mathrm{~m}$, které jsme již popsali. Plošné rozsahy nulových hodnot se však dále zvětšily na úkor ploch $s$ vyššími hodnotami uhlonosnosti. Tyto změny jsou patrné ze srovnání jednotlivých modelů (obr. 1, 2, 3), ale také z porovnání procentuálních hodnot uhlonosnosti. Jak jsme již uvedli, hodnoty tohoto parametru pro mezní mocnost $10 \mathrm{~cm}$ se pohybovaly v intervalu od nuly do $2,57 \%$, pro mezní mocnost $0,40 \mathrm{~m}$ v intervalu od nuly do $1,97 \%$, zatímco pro mezní mocnost $80 \mathrm{~cm}$ se hodnoty pohybují v intervalu od nuly do 2,57\%. Tato hodnota je však extrémní a byla zaznamenána v jediném vrtu. Jako extrémní lze označit i hodnoty v intervalu 1,1-1,5\%, které se v souboru vyskytují pouze ve dvou př́padech. $\mathrm{V}$ naprosté většině plochy vývoje svrchních hrušovských vrstev se hodnoty uhlonosnosti pohybují pod hodnotou $1 \%$, přičemž na většině plochy je uhlonosnost vypočtená z výskytu slojí o mocnosti větší než $80 \mathrm{~cm}$ nulová. To svědčí o nízkém zastoupení slojí větších mocností, které se vyskytují pouze na západě post-erozivního výskytu svrchních hrušovských vrstev.

\section{Diskuze}

Ze srovnání modelů celkové mocnosti uhelných poloh a procentuální uhlonosnosti vyplývá, že si zachovávají obdobný charakter. Jsou pro ně charakteristické následující rysy:

1. nejvyšší hodnoty všech typů uhlonosnosti se nacházejí na západě plochy post-erozivního výskytu svrchních hrušovských vrstev,

2. oblast zvýšených hodnot uhlonosnosti je protažena ve směru SV-JZ a nachází se západně od orlovské struktury,

3. plochy zvýšených hodnot mají ostrůvkovitý charakter, 4. východním směrem se hodnoty uhlonosnosti rychle snižují, objevují se oblasti s velmi nízkými i nulovými hodnotami uhlonosnosti, které zejména u uhlonosnosti s vyššími mezními hodnotami mocnosti zvětšují svou plochu.

Popsané základní trendy vývoje uhlonosnosti svrchních hrušovských vrstev potvrzují správnost předchozích 
výsledků vývoje uhlonosnosti této vrstevní jednotky, jak je publikovali Žídková et al. (1997), prrípadně Ševčík (1989). Z hlediska sedimentologického vývoje svrchních hrušovských vrstev se tak potvrzuje předpoklad, že vývoj této jednotky probíhal v podmínkách, které nebyly vhodné pro rozvoj uhlonosné sedimentace. Nepochybně jde o etapu složitého vývoje pánve v období mezi dvěma významnými mořskými ingresemi v pánvi, která vedla ke vzniku skupiny faunistických horizontů Františky v jejím stratigrafickém podloží a skupiny faunistických horizontů Enny v jejich stropu. Z lokalizace vyšších hodnot uhlonosnosti na Z a nízkých hodnot tohoto parametru na V, i z celkového charakteru sedimentologického vývoje vrstevní jednotky, lze usuzovat, že zachovaná plocha vývoje svrchních hrušovských vrstev pravděpodobně odpovídá v. křídlu preerozivní pánve, zatímco z. křídlo pánve se $\mathrm{z}$ důvodů postkarbonské eroze nedochovalo.

Zjištěný vývoj uhlonosnosti svrchních hrušovských vrstev není nijak překvapivým zjištěním. Jde jen o potvrzení známých informací o báňských a technicko-ekonomických možnostech využití uhelných slojí této vrstevní jednotky. Sestavené modely vývoje uhlonosnosti prokazují, že sloje větších mocností se ve svrchních hrušovských vrstvách vyskytují ojediněle (jak vyplývá z jiných hodnocení, uhelné sloje mají také často zvýšené hodnoty popelnatosti). Ze srovnání s výsledky, které uvádí např. Žídková et al. (1997) i Ševčík (1989), patří svrchní hrušovské vrstvy k vrstevním jednotkám, jejichž uhlonosnost je z vrstevních jednotek hornoslezské pánve nejnižší. Příčiny tohoto vývoje je třeba nepochybně hledat v sedimentologickém vývoji vrstevní jednotky a v paleogeografických podmínkách panujících v hornoslezské pánvi v okolí hranice spodních a svrchních ostravského souvrství. Jejich poznání však bude vyžadovat ještě další podrobnější výzkum.

\section{Závěr}

Výzkum vývoje uhlonosnosti svrchních hrušovských vrstev v české části hornoslezské pánve zpřesnil naše představy o prostorovém vývoji uhelných slojí této vrstevní jednotky. Výsledky potvrdily již dříve známou skutečnost, že uhlonosnost svrchních hrušovských vrstev je velmi nízká, nejnižší ze všech vrstevních jednotek ostravského souvrství. Vyšší hodnoty uhlonosnosti se nacházejí v ploše z. od orlovské vrásy. Východním směrem uhlonosnost rychle klesá a objevují se plochy s velmi nízkou i nulovou uhlonosností. Maxima uhlonosnosti $\mathrm{U}_{\mathrm{A}}{ }^{10}$ a $\mathrm{U}_{\mathrm{L}}{ }^{40}$ se překrývají pouze v s. úseku příborské části pánve, naopak maximum uhlonosnosti $\mathrm{U}_{\mathrm{L}}^{80}$ se nachází v oblasti jv. části ostravské aglomerace.

Tyto informace mají význam nejen pro poznání geologického vývoje paralické molasy hornoslezské pánve, ale jsou důležité i z báňského hlediska. V současné době se v ČHP uhelné sloje svrchních hrušovských vrstev s výjimkou dolu Paskov netěží a s ohledem na jejich výskyt není pravděpodobné, že by byly hornicky zpřístupněny. Studium vývoje této vrstevní jednotky je však nepochybně zajímavé z hlediska poznání podmínek vývoje paralické sedimentace $v$ hornoslezské pánvi. Je však třeba poznamenat, že přesnější závěry o této etapě vývoje hornoslezské pánve by vyžadovaly vyhodnocení řady dalších parametrů a další studium s využitím nových metod výzkumů, pro které však často schází podrobnější geologická, zejména však hmotná dokumentace.

Sestavené modely uhlonosnosti přesto představují zajímavý příspěvek k dokreslení sedimentologických podmínek panujících v této etapě vývoje hornoslezské pánve. Nepochybně jde také o informace využitelné pro hodnocení možností báňského využití uhlonosných sekvencí ostravského souvrství v české části hornoslezské pánve.

\section{Poděkování}

Př́prava článku byla podpořena projektem SP2012/24.

\section{Literatura}

Beneš, L. - Jirásek, J. - Hýlová, L. - Sivek, M. (2013 - v tomto čísle): Mocnost svrchních hrušovských vrstev (namur) v české části hornoslezské pánve. - Geologické výzkumy na Moravě a ve Slezsku, 20, 1-2, 112-115.

Beneš, L. (2011): Některé otázky geologického vývoje svrchních hrušovských vrstev v české části hornoslezské pánve. - MS, diplomová práce. Hornicko-geologická fakulta VŠB-TU Ostrava.

Ševčík, V. (1989): Uhlonosnost ostravského souvrství (namur A) v československé části hornoslezské černouhelné pánve. - OKD, 32-49, Ostrava.

Žídková, S. - Krejčí, B. - Martinec, P. - Dopita, M. - Brieda, J. (1997): Ostravské souvrství. - In: Dopita, M. (ed.): Geology of the Czech Part of the Upper Silesian Basin, Ministerstvo životního prostředí České republiky, 43-87, Praha. 